\title{
Retroviral Transfer of Antisense Integrin $\alpha 6$ or $\alpha 8$ Sequences Results in Laminar Redistribution or Clonal Cell Death in Developing Brain
}

\author{
Zhiqiang Zhang and Deni S. Galileo \\ Department of Cellular Biology and Anatomy, Medical College of Georgia, Augusta, Georgia 30912-2000
}

To assess the roles of two integrin $\alpha$ subunits $(\alpha 6$ and $\alpha 8)$ in the developing chicken optic tectum, progenitors were infected with retroviral vectors that contained the marker gene lacZ plus antisense sequences from either the $\alpha 6$ or $\alpha 8$ integrin subunit cDNAs. On embryonic day 3 (E3), the vector was injected into tectal ventricles of chicken embryos. On E6, E7.5, E9, or later, chicken embryos were killed, and optic tecta were dissected and processed for histochemical detection of lacZ-positive cells. The antisense-bearing cell clones (descendants of a single infected progenitor) were analyzed for proliferation and migration patterns and were compared with lacZ-only vectorinfected control clones. At E6, both $\alpha 6$ and $\alpha 8$ integrin antisense-containing cell clones were similar to controls. At E7.5, integrin $\alpha 8$ antisense-containing clones exhibited a cell

Neurons born in the mammalian brain migrate long distances along radial glia to new locations, differentiate into specific cell types, develop elaborate morphologies, and form highly specific connections (Rakic, 1985, 1990). This is also true for neurons in the avian optic tectum (Gray et al., 1988; Gray and Sanes, 1991). Many adhesion molecule families participate in the processes mentioned above. Here, we have focused on the integrins. This family contains many $\alpha$ and $\beta$ subunits that heterodimerize to produce more than 20 different receptors (for review, see Hynes, 1992). Functions of integrins include cell adhesion, organization of the actin-based cytoskeleton, and facilitation of cell migration. Integrins can also activate signal transduction pathways, regulate changes in gene expression, and ultimately affect cell survival by regulating apoptosis (Ruoslahti and Reed, 1994; Clark and Brugge, 1995; Meredith and Schwartz, 1997).

We showed previously that $\beta 1$ integrins are essential for migration and survival of developing chick optic tectum cells by using a $\beta 1$ antisense-containing retroviral vector (Galileo et al., 1992). Several possible $\alpha$ subunits could have been involved in mediating the $\beta 1$ antisense effect. Two $\alpha$ integrin subunits that are potentially involved are $\alpha 8$ and $\alpha 6$.

The $\alpha 6$ integrin subunit is expressed in developing chick embryo brain (Bronner-Fraser et al., 1992) and retina (de Curtis et al., 1991; de Curtis and Reichardt, 1993; de Curtis and Gatti,

\footnotetext{
Received Jan. 22, 1998; revised May 21, 1998; accepted June 12, 1998.

This work was supported by a grant from the National Institute for Neurological Disorders and Stroke to D.S.G. We thank Dr. Lou Reichardt for cDNA clones and antibodies, Dr. Rick Horwitz and Dr. Lynn Schnapp for antibodies, Dr. Josh Sanes for helpful comments, and Dr. Richard Cameron for critical discussions.

Correspondence should be addressed to Dr. Deni S. Galileo, Department of Cellular Biology and Anatomy, Medical College of Georgia, Augusta, GA 309122000.

Copyright (ㄷ) 1998 Society for Neuroscience $\quad 0270-6474 / 98 / 186928-11 \$ 05.00 / 0$
}

number reduction in upper laminae (intermediate zone and tectal plate), and at E9, they exhibited a reduction in the ventricular zone as well. Integrin $\alpha 6$ antisense-containing cell clones exhibited no difference in total cell number at E9 but had a net laminar redistribution of more cells in the ventricular zone and less cells in the tectal plate. Our data show that different integrins play different roles during brain development: $\alpha 6$ integrin is essential for migration of tectal cells into specific laminae, and $\alpha 8$ integrin is essential for the survival of optic tectum cells. Also $\alpha 8$ integrin-substrate interactions may suppress early programmed cell death in premigratory and migratory neuroblasts.

Key words: integrin; antisense; neuronal migration; apoptosis; retroviral vector; chicken embryo

1994). Ligands for $\alpha 6 \beta 1$ integrin include laminins (de Curtis et al., 1991; de Curtis and Reichardt, 1993; de Curtis and Gatti, 1994; Delwel et al., 1994) and other molecules (Cheresh and Mecham, 1994). Interactions of $\alpha 6 \beta 1$ integrin with laminin-1 may mediate growth of avian ciliary ganglion neurons during pathfinding (Weaver et al., 1995). $\alpha 6$ integrin is necessary for early Xenopus nervous system development (Lallier et al., 1996), but a role has not been proposed for later stages of CNS development, such as brain cell migration. $\alpha 6$ integrins may regulate apoptosis, because they are upregulated in some tumor cells (Varner and Cheresh, 1996).

The chicken $\alpha 8$ subunit is expressed in optic tectum and retina (Bossy et al., 1991). The $\alpha 8 \beta 1$ integrin receptor can bind to extracellular matrix proteins tenascin-C (tenascin/cytotactin), vitronectin, and fibronectin (Schnapp et al., 1995). $\alpha 8 \beta 1$ integrin receptors mediate interactions of embryonic chick motor and sensory neurons with tenascin-C (Varnum-Finney et al., 1995) and promote attachment, cell spreading, and neurite outgrowth on fibronectin in vitro (Müller et al., 1995). $\alpha 8$ integrin is also likely to be involved in the regulation of axonal and dendritic growth of some neurons in the developing rat CNS (Einheber et al., 1996).

Because $\alpha 8$ and $\alpha 6$ integrins are found in developing tectum, promote neurite outgrowth in vitro, and bind to extracellular molecules found in developing tectum, we hypothesized that they are important during tectal development. Our results suggest that these two integrins may be used simultaneously during brain development in both general and specific manners.

\section{MATERIALS AND METHODS}

Virus production. The retroviral vectors used in this study are shown in Figure 2. pLZx denotes the plasmid encoding the viral genome, whereas 
LZx denotes the virus itself. pLZ14 is a lacZ-only vector that has been described previously (Galileo et al., 1992). pLZ $\alpha 6$ AS was made by ligating a $1.4 \mathrm{~kb} \mathrm{XbaI}-\mathrm{BglII} \mathrm{cDNA}$ fragment of the chicken $\alpha 6$ integrin subunit (de Curtis et al., 1991) (obtained from Dr. Louis F. Reichardt, Howard Hughes Medical Institute, University of California at San Francisco) in the antisense orientation into unique NheI and BglII sites after lacZ in a derivative of pLZ14 (called pLZ14-TCS; data not shown) previously made for the purpose of cloning antisense sequences after the lacZ gene. The restriction enzyme NheI was added to the ligation mixture to reduce background ligation of pLZ14-TCS. The antisense sequences used for pLZ $\alpha 6 \mathrm{AS}$ are targeted against the common $5^{\prime}$ end of both $\alpha 6 \mathrm{~A}$ and $\alpha 6 \mathrm{~B}$ splicing variants. pLZ $\alpha 8 \mathrm{AS}$ was made similarly to pLZ $\alpha 6$ AS by placing a $0.3 \mathrm{~kb} \mathrm{XbaI-Ecl} \mathrm{136II} \mathrm{fragment} \mathrm{of} \mathrm{the} \mathrm{chicken} \alpha 8$ integrin cDNA (Bossy et al., 1991) (obtained from Dr. Louis F. Reichardt) in the antisense orientation into the unique NheI and Pml I sites after lacZ in pLZ14-TCS. The restriction enzymes Pml I and NheI were added to the ligation mixture to reduce background. Here, $X b a \mathrm{I}$ was compatible with and ligated to NheI, and Ecl 136 II was compatible with and ligated to Pml I. Constructs were confirmed by extensive restriction enzyme digestion analysis (data not shown).

Plasmid DNA to be used for virus production by transfection was purified by either Qiagen (Qiagen Inc., Chatworth, CA) or Promega Wizard Maxiprep (Promega, Madison, WI) DNA purification columns according to the recommended procedures. All viral vectors were produced by transient transfection of vector and helper plasmids into the QT6 quail fibrosarcoma cell line (Moscovici et al., 1977). These cells were used because they are highly transfectable by the calcium phosphate precipitation method and contain no endogenous Rous sarcoma virus sequences. To produce virus, $10 \mathrm{~cm}$ dishes of subconfluent QT6 cells were transfected with a mixture of $10 \mu \mathrm{g}$ of vector plasmid plus $10 \mu \mathrm{g}$ of helper plasmid (pBH1210) (Galileo et al., 1992) per plate using the method of Chen and Okayama (1987). Media containing shed virus particles was collected 2 and $3 \mathrm{~d}$ after transfection and concentrated by centrifugation at $15,000 \mathrm{rpm}(\sim 30,000 \times g)$ in a Beckman SW28 rotor for $2.5 \mathrm{hr}$, or at $13,000 \mathrm{rpm}$ for $12 \mathrm{hr}$. Both conditions resulted in good recovery of concentrated virus. Titers were determined by infection of QT6 cells in the presence of $10 \mu \mathrm{g} / \mathrm{ml}$ polybrene and subsequent staining for lacZ (see below) $2 \mathrm{~d}$ later.

Embryos. Fertilized White Leghorn chicken eggs were obtained from SPAFAS (Roanoke, IL) and incubated at $37.5^{\circ} \mathrm{C}$ until the desired Hamburger and Hamilton (1951) stage was reached. Embryos were injected with viral concentrate at stages 16-18 [embryonic day 3 (E3)]. Viral concentrates $(1-2 \mu \mathrm{l})$ were injected into the right tectal ventricle (Gray et al., 1988) using a pulled glass micropipette and a picopump (World Precision Instruments, Sarasota, FL). Before injection, 20-25 $\mu \mathrm{l}$ of concentrate was mixed with $1 \mu \mathrm{l}$ of $1 \mathrm{mg} / \mathrm{ml}$ polybrene and $2 \mu \mathrm{l}$ of $1 \%$ fast green dye. After injection, a few drops of sterile-filtered ampicillin (50 $\mu \mathrm{g} / \mathrm{ml}$ ) were placed on the embryo before the egg window was sealed with transparent tape, and the eggs were returned to the incubator. At appropriate times thereafter, embryos were removed from the eggshells, and tecta were dissected in calcium- and magnesium-free Tyrode's solution and fixed in $2 \%$ formaldehyde (ACS grade, Sigma, St. Louis, MO) in PBS (150 mm NaCl, $15 \mathrm{~mm}$ sodium phosphate, $\mathrm{pH} 7.3)$ for $1-2 \mathrm{hr}$. Tecta were then rinsed in PBS several times and incubated overnight in a solution containing 5 -bromo-4-chloro-3-indolyl- $\beta$-D-galactoside (X-gal; $1 \mathrm{mg} / \mathrm{ml}$ ), $60 \mathrm{~mm}$ potassium ferricyanide, $60 \mathrm{~mm}$ potassium ferrocyanide, and $2 \mathrm{mM} \mathrm{MgCl}_{2}$ in PBS. The next day, tecta were rinsed several times in PBS, post-fixed in $2 \%$ formaldehyde $/ 2 \%$ glutaraldehyde in PBS, rinsed in PBS, and cleared in $70 \%$ glycerol. LacZ-positive cells were visualized with a dissecting microscope. Gathering of data concerning cell number and distribution of cells within clones was performed using a compound microscope. Sections containing clones of lacZ-positive cells were handcut and mounted on glass slides in glycerol. Every injection experiment involved injecting some embryos with an antisense vector and some embryos with the lacZ-only vector for direct comparison. Student's $t$ test was used to compare mean numbers of cells/clone between lacZ-only and antisense-infected tecta.

Immunohistochemistry. Tecta were fixed by immersion in $2 \%$ formaldehyde (ACS grade) in PBS for $\sim 2 \mathrm{hr}$, rinsed in PBS, and sunk overnight in $30 \%$ sucrose in PBS at $4^{\circ} \mathrm{C}$. Tecta were submerged in Tissue-Tek O.C.T. compound (Miles, Inc., Elkhart, IN) and frozen on dry ice. Cryostat sections were cut at $\sim 10 \mu \mathrm{m}$ thickness and air-dried onto glass Superfrost Plus slides (Fisher Scientific, Pittsburgh, PA). To detect the low levels of $\alpha 6$ and $\alpha 8$ integrins present in the optic tectum, we used an indirect triple-layer immunofluorescent technique. For this, sections were incubated in primary antibody against either the $\alpha 6$ (P2C62C4 monoclonal antibody obtained from Dr. A. F. Horwitz, University of Illinois) or $\alpha 8$ (polyclonal anti-human $\alpha 8$ obtained from Dr. Lynn Schnapp, Mount Sinai Medical Center; polyclonal anti-chicken $\alpha 8$ obtained from Dr. Louis F. Reichardt) subunit of integrin in PBS containing $5 \%$ fetal bovine bovine serum (FBS) and $0.03 \%$ Triton X-100 for $0.5-1 \mathrm{hr}$ at room temperature. Sections were then rinsed in PBS/FBS, incubated in a biotinylated secondary antibody raised against the species of the primary antibody (mouse or rabbit) in PBS/FBS/Triton X-100 for $0.5-1 \mathrm{hr}$, rinsed, and incubated in fluochrome-conjugated streptavidin in PBS/FBS/Triton X-100 for $0.5-1 \mathrm{hr}$. Immunofluorescent staining was visualized on a Nikon Microphot microscope equipped for epifluorescence.

Tests of antisense suppression. To test our antisense-containing vectors for their ability to attenuate their target integrin subunit, tecta were infected in vivo and then optic tectum (OT) cells were recovered several days later and analyzed for integrin expression by flow cytometry. Tectal ventricles were injected with virus at E3 as above for clonal analysis. On E7, tecta were dissected, the meninges were removed, and tecta were minced and incubated in $0.05 \%$ trypsin $/ 0.02 \%$ EDTA for $10 \mathrm{~min}$. A solution containing soybean trypsin-inhibitor and DNase I was then added, and the tissue was dissociated into single cells by trituration as described previously (Galileo et al., 1992). Single cells were pelleted gently by centrifugation and resuspended in $1 \%$ formaldehyde (ACS grade) for $30 \mathrm{~min}$ for fixation. Cells were gently pelleted, rinsed in PBS, and then rinsed in PBS containing 5\% FBS (PBS/FBS). Cells were immunostained for lacZ and either $\alpha 6$ or $\alpha 8$ integrin by incubating cells in PBS/FBS containing anti-lacZ antibodies (Galileo et al., 1992), antiintegrin antibodies (see above method for immunostaining of tissue sections), and $0.03 \%$ Triton X-100 for $0.5 \mathrm{hr}$ at room temperature. Cells were pelleted, rinsed in PBS/FBS, and resuspended in secondary donkey anti-primary species conjugated to R-phycoerythrin (Jackson Immunochemicals, West Grove, PA) to visualize lacZ-positive cells and biotinylated antibodies against the species in which the anti-integrin primary antibody was raised in PBS/FBS/Triton X-100 for $0.5 \mathrm{hr}$. After cells were rinsed in PBS/FBS, they were incubated in streptavidin-fluorescein in $\mathrm{PBS} / \mathrm{FBS} /$ Triton $\mathrm{X}-100$ for $0.5 \mathrm{hr}$ to visualize integrin staining. Cells were rinsed in PBS/FBS and then subjected to two-color flow cytometry analysis on a Becton Dickinson (Mountain View, CA) FACS/Calibur. The level of integrin subunit immunostaining was analyzed on infected lacZ-positive cells as well as on uninfected lacZ-negative cells.

The vector LZ $\alpha 6 \mathrm{AS}$ was also tested for its ability to reduce $\alpha 6$ integrin expression in infected QT6 cells in vitro, which express this subunit. For this, QT6 cell cultures were infected with either LZ14 or LZ $\alpha 6$ AS. Approximately 1 week later, cells were removed from the dish by incubation in $0.05 \%$ trypsin $/ 0.02 \%$ EDTA solution for $1-2$ min and resuspended as single cells. Cells were gently pelleted and resuspended in $1 \%$ formaldehyde (ACS grade) for fixation for $30 \mathrm{~min}$. After cells were rinsed in PBS/FBS, they were incubated in fluorescein-anti-mouse and either Texas Red-anti-rabbit or R-phycoerythrin-anti-rabbit in PBS/FBS/ Triton X-100 for $30 \mathrm{~min}$. Cells were rinsed and subjected to two-color flow cytometry analysis on a FACS/Calibur (Becton Dickinson) or an EPICS ELITE (Coulter Electronics, Hialeah, FL) flow cytometer. Means and SDs of plots were calculated using Becton Dickinson or Coulter software.

Flow cytometry analysis of end labeling. To demonstrate that the $\alpha 8$ integrin subunit is important for the survival of OT cells, tecta were infected in vivo, and single cells from E7-E8 tecta were analyzed for their pattern of DNA end labeling by flow cytometry. The end-labeling method used is an extremely sensitive fluorescent method that we developed to demonstrate widespread apoptosis in tissue sections during normal early OT development (Zhang and Galileo, 1998). For this, tectal ventricles were injected with virus on E3 as above for clonal analysis. On $\mathrm{E} 8$, tecta were dissociated into single cells as above except that no DNase I was used. Cells were fixed in suspension as above, rinsed with PBS, and then resuspended in $0.1 \%$ Triton X-100 in PBS for $10 \mathrm{~min}$. After cells were rinsed with PBS twice, they were resuspended in a terminal transferase reaction mixture $(15 \mathrm{U} \mathrm{TdT} / 100 \mu \mathrm{l}, 0.05 \mathrm{nmol}$ digoxigenin-dUTP/ $100 \mu \mathrm{l}$, and $1 \times \mathrm{TdT}$ buffer) for $1 \mathrm{hr}$ at $37^{\circ} \mathrm{C}$. Cells were then rinsed twice in PBS/FBS and resuspended in monoclonal anti-digoxigenin (Boehringer Mannheim, Indianapolis, IN) and polyclonal anti-lacZ antibody in $\mathrm{PBS} / \mathrm{FBS}$ for $30 \mathrm{~min}$ at room temperature. After cells were rinsed in PBS/FBS, they were resuspended in biotinylated goat anti-mouse in PBS/FBS for $30 \mathrm{~min}$ at room temperature. After cells were rinsed, they were resuspended in R-phycoerytherin-anti-rabbit and streptavidin- 
fluorescein for $30 \mathrm{~min}$ at room temperature. After cells were rinsed, they were resuspended and subjected to analysis on a FACS/Calibur (Becton Dickinson) flow cytometer. Fluorescent end labeling was analyzed on infected lacZ-positive cells as well as on uninfected lacZ-negative cells. Means and SDs of histogram plots were calculated using Becton Dickinson Cell Quest software.

\section{RESULTS}

\section{Integrin $\alpha 8$ and $\alpha 6$ expression in developing tectum}

To demonstrate that $\alpha 6$ and $\alpha 8$ integrins and some of their known substrates are expressed in the developing chicken optic tectum specifically during periods of cell migration, we immunostained frozen sections of developing tecta. A sensitive triplelayer immunofluorescent staining method was used to visualize the low levels of $\alpha 6$ and $\alpha 8$ integrin subunit present in the optic tectum. Others have reported $\alpha 6$ integrin expression in the developing brain and spinal cord (Bronner-Fraser et al., 1992). Bossy et al. (1991) reported $\alpha 8$ integrin expression in E6 tectum, before neuronal migration occurs. We wished to extend these results to tectum specifically when cell migration occurs. E7 tectum sections were immunostained with two different polyclonal antibodies specific for integrin $\alpha 8$ : one against chicken $\alpha 8$ and the other against human $\alpha 8$. Use of both of these antibodies resulted in a low-level widespread immunostaining pattern where cell surface outlines were visible. Figure $1 A$ shows immunostaining using the anti-chicken antibody where immunoreactivity appeared to be elevated in the axon-rich intermediate zone (IZ). For $\alpha 6$ integrin, a monoclonal antibody specific for chicken $\alpha 6$ integrin was used (Bronner-Fraser et al., 1992). Immunostaining was widespread such that cell surface outlines were weakly visible (Fig. 1B). Staining appeared to be higher in the germinative ventricular zone (VZ). Control sections in which the primary antibodies were omitted showed no visible staining. Contrast enhancement was used in these photomicrographs to emphasize the uneven distribution of the different subunits.

We found two integrin $\alpha 8 \beta 1$ substrates, tenascin-C and fibronectin, expressed during neuronal migration. As shown in Figure $1 C$, moderate to high levels of anti-tenascin immunostaining were present at $\mathrm{E} 9$, primarily in the axonal layers, the IZ and stratum opticum (just deep to the meninges), as others have reported (Perez and Halfter, 1994; Yamagata et al., 1995). Antifibronectin immunostaining was widespread and present at low levels (Fig. 1D). The brightest staining was around blood vessels and in the meninges. Staining in the neural tissue was present at low levels in the tectal plate (TP) and tapered off to be undetectable in the VZ. Fibronectin has been found previously on mammalian cortical radial glia (Sheppard et al., 1991) but has not been reported in the developing tectum. Thus, we have found immunoreactivity for both $\alpha 8$ and $\alpha 6$ integrin subunits and two possible substrates for $\alpha 8 \beta 1$ integrin in developing tectum during periods of neuronal migration. We could not detect staining for the $\alpha 6 \beta 1$ integrin substrate laminin within the neural tissue of the optic tectum by triple-layer immunofluorescence [data not shown; 31-2 monoclonal antibody (Bayne et al., 1984)].

\section{Construction and testing of antisense vectors}

We constructed two recombinant retroviral vectors (LZ $\alpha 6 \mathrm{AS}$ and LZ $\alpha 8$ AS) that contained the lacZ marker gene plus sequences from the chicken $\alpha 6$ or $\alpha 8$ integrin subunits cloned in the antisense orientation (Fig. 2). These sequences both spanned the translational initiation site of their target messages and were cloned directly after lacZ in the vector constructs. LacZ served as a permanent marker to identify infected cell progeny to allow the
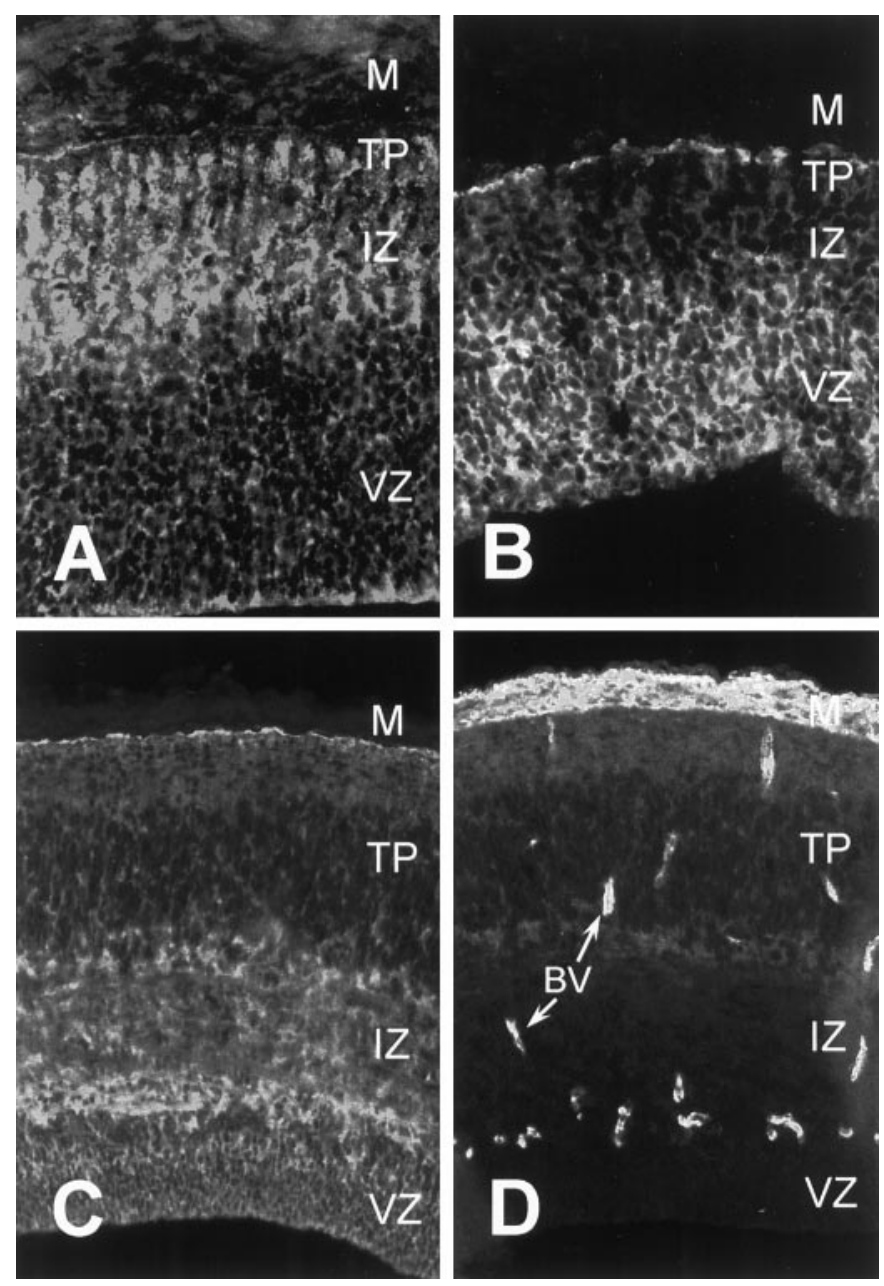

Figure 1. Expression of integrin subunits and substrates in the developing optic tectum. Cryosections of developing optic tectum were immunostained with antibodies against integrin $\alpha 8(A)$, integrin $\alpha 6(B)$, tenascin-C $(C)$, and fibronectin $(D) . A, B$, E7 tectum; $C, D$, E9 tectum. For all parts, the ventricular surface is down. Arrows in $D$ denote blood vessels $(B V)$. $M$, Meninges; $V Z$, ventricular zone; $I Z$, intermediate zone; $T P$, tectal plate. See Results for details.

distribution, cell number, and migration patterns to be followed. This strategy was used previously for the construction of the vector LZ16 for attenuating expression of the $\beta 1$ integrin subunit (Galileo et al., 1992). This strategy was chosen also because there is only one possible transcript (from the viral LTR), and thus every cell containing the lacZ gene product contains the desired antisense sequence at the end of the lac $Z$ message. Here, we provide evidence that $\alpha 6$ integrin is necessary for some tectal cells to migrate out of the ventricular zone and into the tectal plate. We also provide evidence that $\alpha 8 \beta 1$ integrin is involved in general survival and growth of optic tectum cells.

To test the ability of LZ $\alpha 8$ AS and LZ $\alpha 6$ AS to attenuate their respective integrins, we produced virions and infected $\mathrm{E} 3$ tecta in vivo. Four days later, tecta were gently dissociated and cells were doubly immunostained with antibodies against lacZ and either $\alpha 8$ or $\alpha 6$ integrin. They then were subjected to two-color analysis by flow cytometry. We found that the mean level of the immunostaining peak for $\alpha 8$ integrin on OT cells infected with LZ $\alpha 8$ AS was reduced significantly compared with OT cells infected with LZ14 (Fig. 3) $(p<0.0001)$ as well as compared with uninfected 


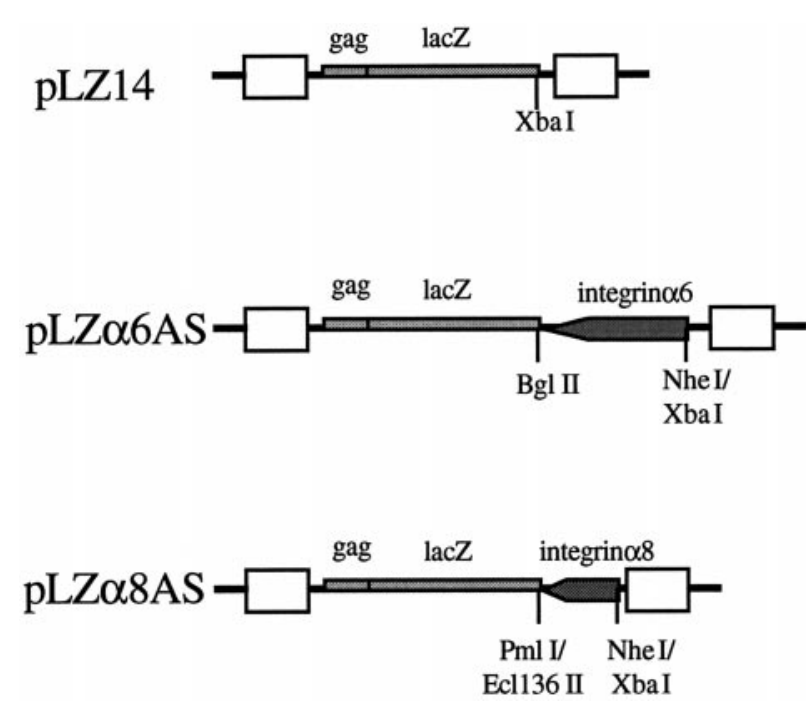

Figure 2. Retroviral vectors used in this study. pLZ14, pLZ $\alpha 6$ AS, and pLZ $\alpha 8 A S$ encode gag-lacZ fusion proteins. $\mathrm{pLZ} \alpha 6 \mathrm{AS}$ and $\mathrm{pLZ} \alpha 8 \mathrm{AS}$ are similar to pLZ14 with the addition of an antisense sequence ( filled arrow) against either the $\alpha 6$ or the $\alpha 8$ integrin subunit. Boxes indicate viral long terminal repeats. Key restriction sites used in construction of the antisense vectors are marked. See Materials and Methods and Results for details.
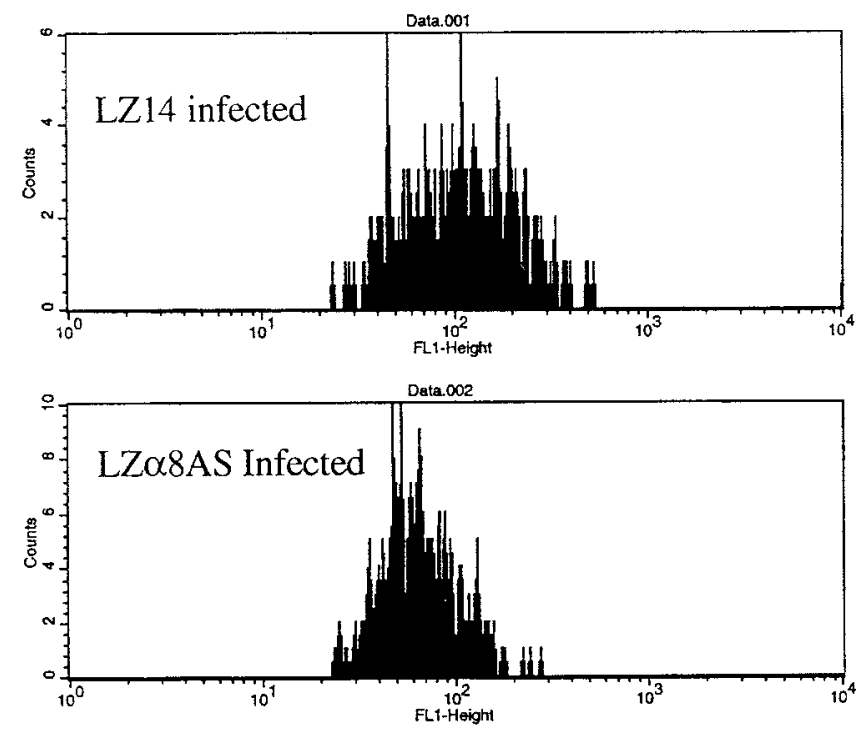

Figure 3. Analysis of $\alpha 8$ integrin immunostaining of optic tectum cells by flow cytometry. Tecta were injected with either LZ14 or LZ $\alpha 8$ AS on E3, and dissociated tectal cells were analyzed for $\alpha 8$ integrin immunostaining on E7. The top panel shows $\alpha 8$ integrin levels in cells infected by LZ14. The bottom panel shows $\alpha 8$ integrin levels in cells infected by LZ $\alpha 8$ AS $(p<0.0001)$.

cells from the same tecta ( $p<0.05$; data not shown). We found that the mean level of the immunostaining peak for $\alpha 6$ integrin on OT cells infected with LZ $\alpha 6$ AS was also reduced (data not shown), although the results were less consistent.

To further test LZ $\alpha 6$ AS, we analyzed by flow cytometry infected QT6 cells [a quail fibrosarcoma cell line (Moscovici et al., 1977)], which express a higher level of $\alpha 6$ integrin. QT6 cells were dissociated, doubly immunostained, and analyzed. Levels of $\alpha 6$ integrin immunostaining were markedly reduced on QT6 cells $(p<0.0001)$ (Fig. 4) infected with LZ $\alpha 6$ AS compared with those infected with a lacZ-only control vector LZ10 [a functional equiv-

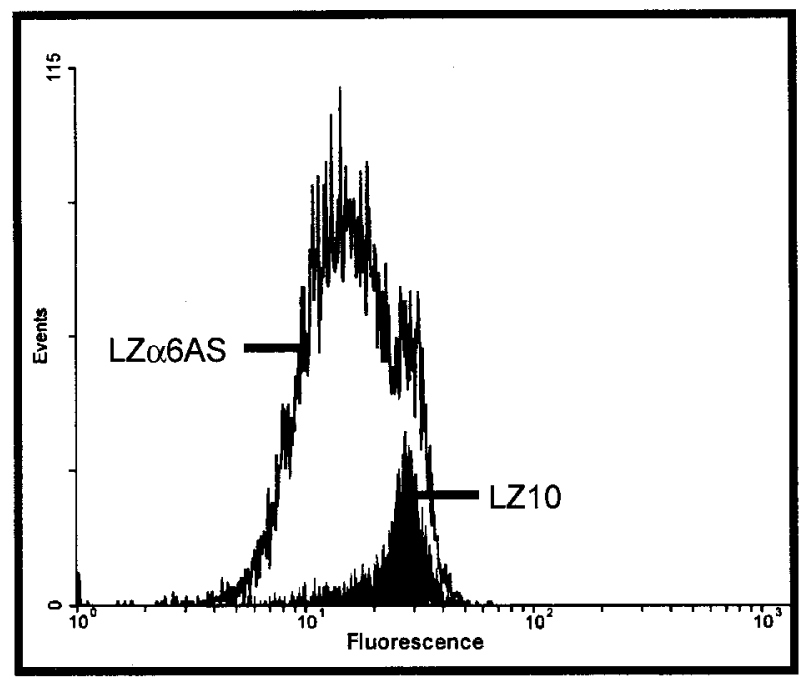

Figure 4. Analysis of $\alpha 6$ integrin immunostaining of QT6 cells by flow cytometry. QT6 cells were infected with either LZ10 or LZ $\alpha 6$ AS and analyzed for $\alpha 6$ integrin after dissociation and immunofluorescent staining. The filled graph represents levels of $\alpha 6$ integrin in control LZ10infected cells. The unfilled graph represents levels of $\alpha 6$ integrin in LZ $\alpha 6$ AS-infected cells $(p<0.0001)$.

alent of LZ14; see Galileo et al. (1990, 1992)]. Thus, the vectors LZ $\alpha 8 \mathrm{AS}$ and LZ $\alpha 6 \mathrm{AS}$ attenuated their targeted integrins significantly in OT cells infected in vivo and in QT6 cells in vitro.

\section{Effects of $\alpha \mathbf{6}$ integrin antisense in vivo}

At E3, we infected progenitor cells in the developing chick optic tectum with retroviral vectors containing antisense sequences against the $\alpha 6$ or $\alpha 8$ integrin subunit to assess cell requirements for these molecules during proliferation and migration. Experiments contained embryos injected with each type of virus (some antisense and some lacZ-only control). Groups of tecta (both virus types) were then fixed at E6, E7.5, E9, and E12, histochemically stained for lacZ, and sectioned by hand. Clones of lacZpositive cells were identified and analyzed as before (Galileo et al., 1992). Features of lacZ-only (LZ14) and lacZ-antisense (LZ $\alpha 6 \mathrm{AS}$ or LZ $\alpha 8 \mathrm{AS})$ were compared.

\section{E6}

At E6, the tectum is composed of a thick VZ with a thin superficial marginal zone made up of axons from the large multipolar efferent neurons. Cells infected on E3 with the control vector (LZ14) have divided to form marked clones of $\sim 12$ cells each. These clones appeared as radial arrays of cells that spanned the thickness of the ventricular zone.

At E6, the appearance (Fig. 5, top) and average size of $\alpha 6$ integrin antisense-expressing clones was not different from that of control LacZ-only-expressing clones of $\sim 12$ cells $(p=0.25)$ (Table 1). Thus, the presence of $\alpha 6$ antisense sequences did not affect proliferation or radial stacking of cells within the ventricular zone.

\section{E9}

We did not analyze LZ $\alpha 6$ AS cell clones at E7.5. At E9, LZ $\alpha 6$ AS cell clones appeared to be normal by visual inspection (Fig. 5, bottom). The histochemical staining for lacZ in the LZ $\alpha 6 \mathrm{AS}$ clones at E9 appeared similar to LZ14 clones. After quantitation, there was no difference in the total cell number per clone between 

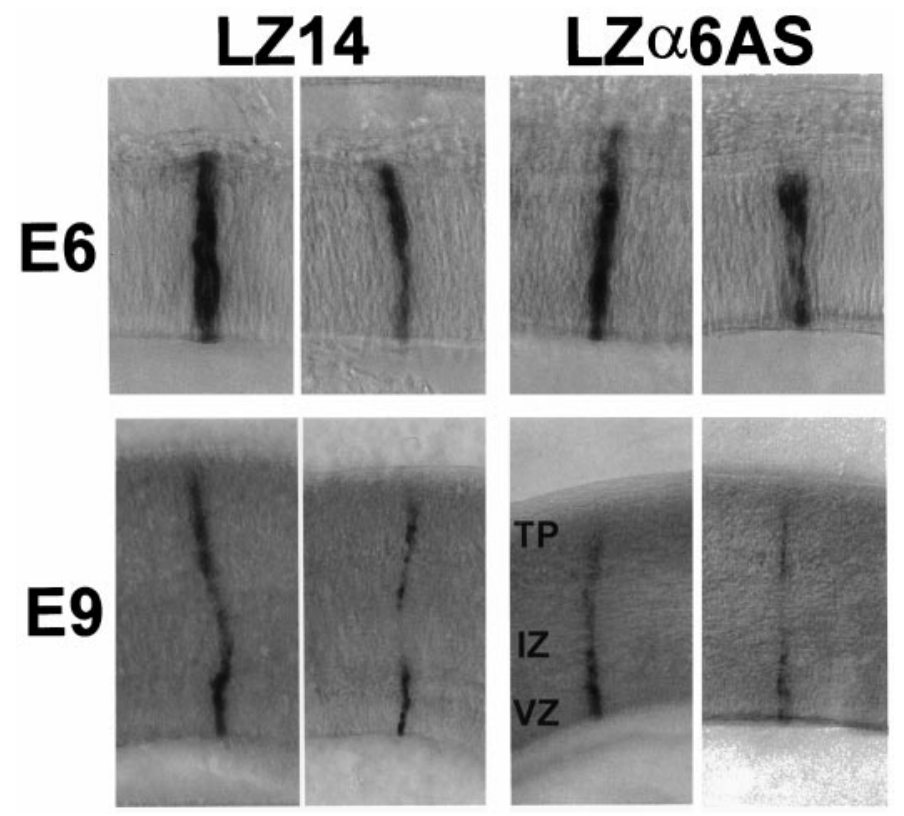

Figure 5. Appearance of LZ $\alpha 6$ AS-infected cell clones in vivo. Tecta were injected with LZ14 or LZ $\alpha 6$ AS on E3 and processed for X-gal histochemistry on E6 (top) and E9 (bottom). Shown are LZ14 control clones (left) or LZ $\alpha 6$ AS clones (right) in thick sections.

Table 1. Effect of LZa6AS on E6 tectal cells

\begin{tabular}{lll} 
Vector & Number of clones analyzed & Mean cell number/clone \\
\hline LZ $\alpha 6$ AS & 218 & $11.4 \pm 0.6$ \\
LZ14 & 208 & $12.5 \pm 0.7$
\end{tabular}

$\overline{\text { Tectal ventricles were injected with LZ } \alpha 6 \mathrm{AS} \text { or LZ14 on E3 (approximately stage }}$ 17), and tecta were analyzed at E6. The size of a clone of both control (LZ14) and experimental (LZ $\alpha 6 \mathrm{AS}$ ) clones is given as mean cell number \pm SEM. Significance of differences between mean numbers of cells was assessed by the two-tailed $t$ test. $p=0.25$.

Table 2. Effects of LZa6AS on cell number and distribution at E9

Clonal cell distri-

\begin{tabular}{lccc} 
bution & LZ $\alpha 6$ AS $(n=166)$ & LZ14 $(n=128)$ & $p$ value \\
\hline Total clone & $18.0 \pm 0.8(100 \%)$ & $19.8 \pm 1.0(100 \%)$ & 0.18 \\
Tectal plate & $5.0 \pm 0.4(28 \%)$ & $9.0 \pm 0.6(45 \%)$ & $<0.0001$ \\
Intermediate zone & $3.0 \pm 0.2(17 \%)$ & $3.0 \pm 0.2(15 \%)$ & 0.86 \\
Ventricular zone & $10.0 \pm 0.4(55 \%)$ & $7.7 \pm 0.4(39 \%)$ & $<0.01$
\end{tabular}

Tectal ventricles were injected with LZ $\alpha 6$ AS or LZ14 on E3 (approximately stage 17), and tecta were analyzed at E9. For the vector LZ $\alpha 6 \mathrm{AS}$, the number of clones used for analysis was $166(n=166)$; for the vector LZ14, the number of clones used for analysis was $128(n=128)$. The cell distribution of mean cell number in each layer, ventricular zone, intermediate zone, and tectal plate, as well as mean total cells per clone, are expressed as the mean cell number \pm SEM. Significance of differences between control and experimental mean numbers of cells was assessed by the two-tailed $t$ test.

$\alpha 6$ integrin antisense-expressing and the control LZ14 clones. However, there was a significant difference in the distribution of the cells within two of the three laminae (Table 2). Differences in cell numbers between LZ $\alpha 6$ AS and control LZ14 clones were found in the tectal plate $(p<0.0001)$ and ventricular zone $(p<$ $0.01)$. There was no difference in the net cell number present in the intermediate zone $(p=0.86)$. There were more cells $(2.3$ cells more) in the ventricular zone and fewer cells (four cells less) in the tectal plate for LZ $\alpha 6$ AS clones compared with LZ14 control clones. Although the number of additional cells in the ventricular zone does not equal the number of fewer cells in the tectal plate, it is possible that the cells missing from the tectal plate are the same cells remaining in the ventricular zone. If this is correct, our results suggest that integrins containing an $\alpha 6$ subunit are necessary for the correct radial migration of a subpopulation of tectal cells destined for the tectal plate. Introduction of $\alpha 6$ integrin antisense appears to have delayed or prevented the migration of this subpopulation of tectal cells from the ventricular zone into the tectal plate.

From the results in Table 2, if LZ $\alpha 6$ AS affected the majority of clones to a similar extent, then there would be corresponding shifts in the cells within the affected laminae among the majority of clones. To determine whether this was the case, relative frequency histograms were plotted for the VZ and TP of LZ14 and LZ $\alpha 6$ AS clones at E9 (Fig. 6). These histograms show that within the $\mathrm{VZ}$ there was a corresponding, small shift in the population of LZ $\alpha 6$ AS clones toward containing more cells (Fig. 6, top). Also, for the TP there was a corresponding shift in the population of LZ $\alpha 6$ AS clones toward containing fewer cells (Fig. 6, bottom). These results suggest that most of the LZ $\alpha 6$ AS clones were affected similarly.

\section{Effects of $\alpha 8$ integrin antisense in vivo E6}

As shown in Figure 7 (top), typical E6 cell clones of both control (LZ14) and experimental (LZ $\alpha 8$ AS) groups were similar with respect to cell number, distribution, and the intensity of LacZ staining. Statistical analyses of E6 results are presented in Table 3. Cell numbers were similar for both groups $(p=0.49)$. Thus, the presence of $\alpha 8$ integrin antisense sequences did not have an effect on either the proliferation of infected progenitors or the radial stacking of clonal progeny at this stage.

\section{E7.5}

After E6, cells begin to migrate out of the ventricular zone along radial glial cells so that by E7.5 the tectum consists of a ventricular zone, an intermediate zone (the former marginal zone), and a newly forming tectal plate. Typical cell clones are shown in Figure 7 (middle), and it can be seen that less staining is evident in upper laminae of the antisense $\alpha 8$-expressing cell clones. The average total cell number per clone as well as cell number in the tectal plate and the intermediate zone was reduced $(p<0.0001)$ for $\alpha 8$ integrin antisense-expressing cell clones (Table 4). However, the cell number in the ventricular zone of $\alpha 8$ integrin antisense-expressing cell clones was similar to that of control clones $(p=0.65)$. In the control (LZ14) clones, there was a substantial net increase in the total cell number at E7.5 compared with E6 (approximately 10 cells), as well as a substantial redistribution of cells out of the ventricular zone into upper laminae (approximately 10 cells). In $\alpha 8$ antisense-containing clones, there was only a slight net increase in either total cell number at E7.5 compared with E6 (approximately two cells) or redistribution into upper laminae (approximately one cell).

The significant difference between mean numbers of cells in the intermediate zone and tectal plate in LZ14 and LZ $\alpha 8$ AS clones could be attributable to either a large effect on a subpopulation of LZ $\alpha 8 \mathrm{AS}$ clones or a lesser effect on the majority of clones. To distinguish between these two possibilities, results from these two laminae (IZ and TP) are shown as relative frequency histograms in Figure 8. It can be seen for both laminae that most of the population of clones were drastically reduced in 

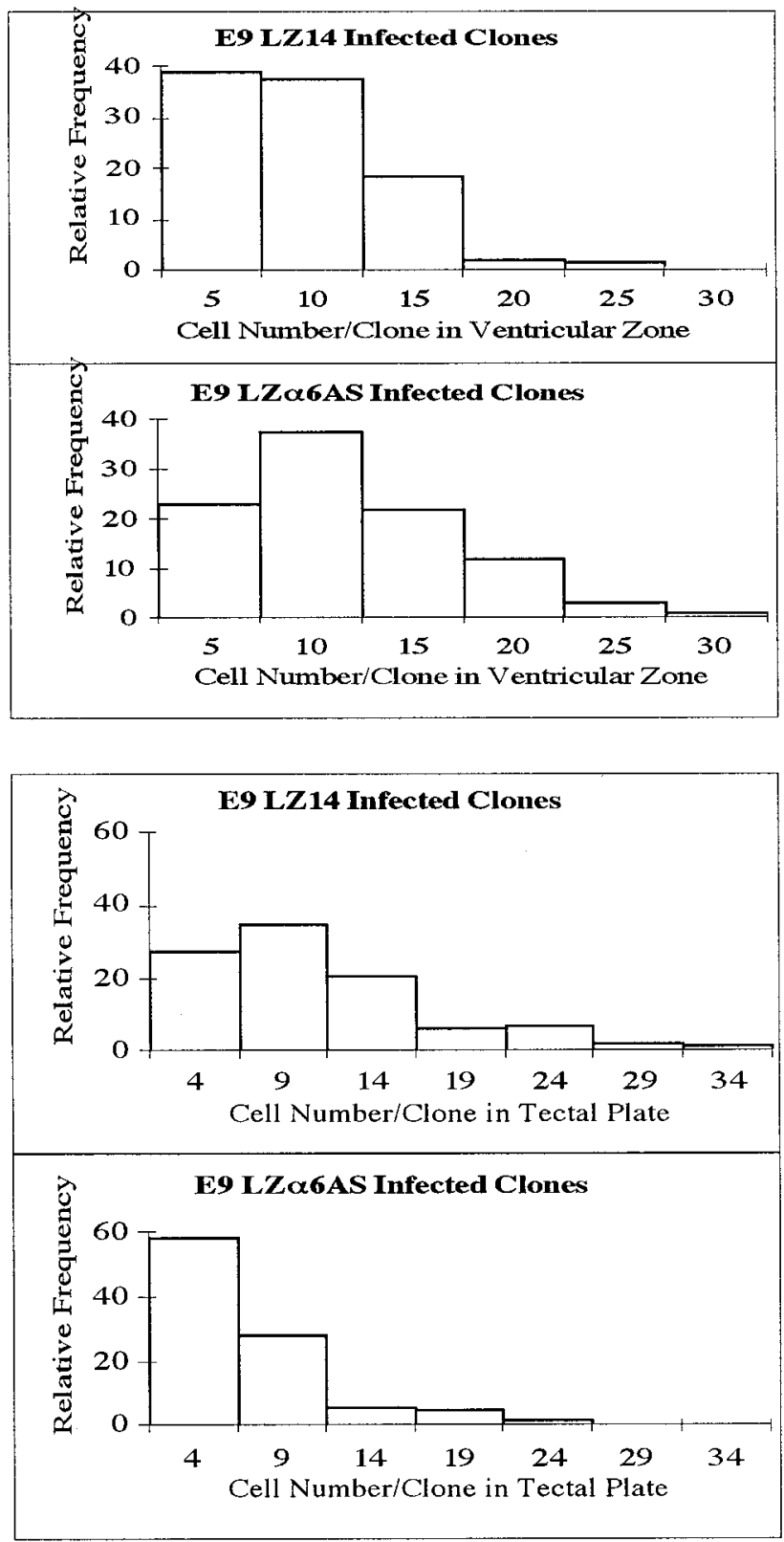

Figure 6. Relative frequency histogram of affected zones in LZ $\alpha 6$ ASinfected tecta at E9. The top panels show the relative frequency distribution of LZ $\alpha 6$ AS- and LZ14-infected cells within the ventricular zone. The bottom panels show the relative frequency distribution of LZ $\alpha 6 \mathrm{AS}-$ and LZ14-infected cells within the tectal plate.

cell number in LZ $\alpha 8$ AS-infected clones. Thus, LZ $\alpha 8$ AS appears to have affected most, if not all, clones.

\section{E9}

Between E7.5 and E9, some proliferation continues and much radial migration occurs, resulting in a substantial thickening of the tectal plate. Shown in Figure 7, bottom, are typical control and $\alpha 8$ antisense-infected cell clones at E9. There was a net increase in total cell number in control clones between E7.5 and E9 of approximately seven cells (Tables 4, 5). However, there was a net decrease in $\alpha 8$ antisense-containing clones by approximately five cells. The mean total cell number in $\alpha 8$ antisense-containing clones and the number in each of the three layers (ventricular

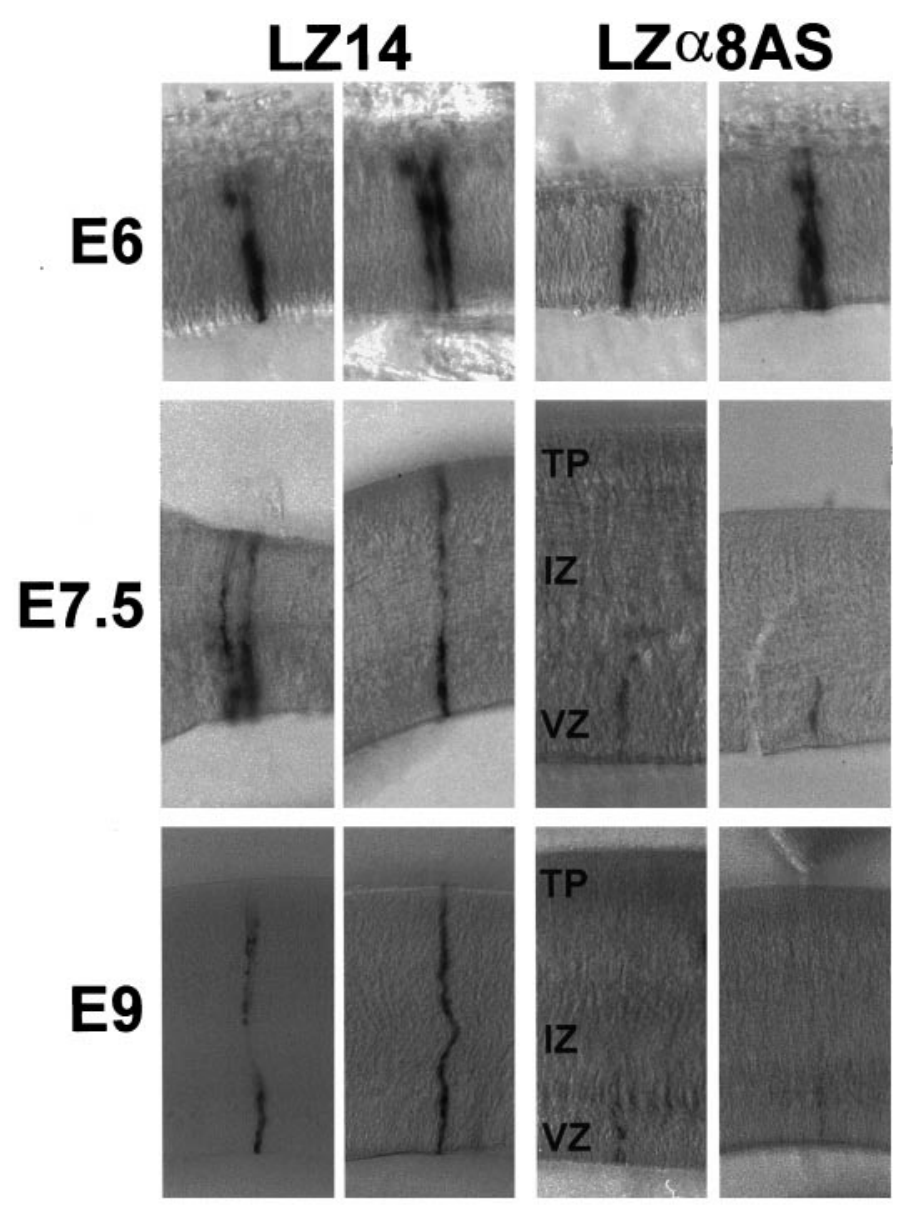

Figure 7. Appearance of LZ $\alpha 8 \mathrm{AS}$-infected cell clones in vivo. Tecta were injected with LZ14 or LZ $\alpha 8 \mathrm{AS}$ on E3 and processed for X-gal histochemistry on E6 (top), E7.5 (middle), or E9 (bottom). Shown are LZ14 control clones (left) or LZ $\alpha 8 \mathrm{AS}$ clones (right) in thick sections.

Table 3. Effect of LZ $\alpha 8 A S$ on E6 tectal cells

\begin{tabular}{lll} 
Vector & Number of clones analyzed & Mean cell number/clone \\
\hline LZ $\alpha 8$ AS & 163 & $11.6 \pm 0.6$ \\
LZ14 & 104 & $10.9 \pm 0.7$
\end{tabular}

Tectal ventricles were injected with LZ $\alpha 8$ AS or LZ14 on E3 (approximately stage 17 ), and tecta were analyzed at E6. The average size of a clone of both control (LZ14) and experimental (LZ $\alpha 8 \mathrm{AS})$ clones is given as mean cell number \pm SEM. Significance of differences between mean numbers of cells was assessed by the two-tailed $t$ test. $p=0.49$.

zone, intermediate zone, and tectal plate) were dramatically reduced compared with those of the control clones $(p<0.0001$ for all comparisons). These decreases suggest that most of the $\alpha 8$ antisense-bearing cells died. Also, in general, $\alpha 8$ antisensebearing cells that were still present were fainter in staining for lacZ, also suggesting that these remaining cells may be dying.

To gain a better understanding of the effects of LZ $\alpha 8 \mathrm{AS}$ on the depletion of cells over time, a relative frequency histogram of the total cell number/clone for LZ $\alpha 8 \mathrm{AS}$ and LZ14 cell clones on E7.5 and E9 is shown in Figure 9. For control LZ14 clones, there was a shift in the population toward slightly larger clones between E7.5 and E9. LZ $\alpha 8$ AS cell clones as a population, however, were shifted relative to controls toward being smaller in cell number at E7.5. This shift toward smaller clones was even more pronounced 


\begin{tabular}{|c|c|c|c|}
\hline $\begin{array}{l}\text { Clonal cell distri- } \\
\text { bution }\end{array}$ & $\mathrm{LZ} \alpha 8 \mathrm{AS}(n=134)$ & $\operatorname{LZ14}(n=55)$ & $p$ value \\
\hline Total clone & $13.7 \pm 0.8(100 \%)$ & $21.2 \pm 2.0(100 \%)$ & $<0.0001$ \\
\hline Tectal plate & $0.4 \pm 0.1(3 \%)$ & $5.0 \pm 0.6(24 \%)$ & $<0.0001$ \\
\hline Intermediate zone & $1.0 \pm 0.2(7 \%)$ & $4.5 \pm 0.6(21 \%)$ & $<0.0001$ \\
\hline Ventricular zone & $12.3 \pm 0.4(90 \%)$ & $11.7 \pm 1.1(55 \%)$ & 0.65 \\
\hline
\end{tabular}

Tectal ventricles were injected with LZ $\alpha 8$ AS or LZ14 on E3 (approximately stage 17), and tecta were analyzed at E7.5. For the vector LZ $\alpha 8 \mathrm{AS}$, the number of clones used for analysis was $134(n=134)$; for the vector LZ14, the number of clones used for analysis was $55(n=55)$. The cell distribution of a mean cell number in each layer, ventricular zone, intermediate zone, and tectal plate, as well as mean total cells per clone, are expressed as the mean cell number \pm SEM. Significance of differences between control and experimental mean numbers of cells was assessed by the two-tailed $t$ test.

at E9. Thus, over time, LZ $\alpha 8 \mathrm{AS}$ cell clones became smaller as a population. These data also are consistent with the notion that this antisense vector caused cells to die.

LZ $\alpha 8$ AS virus-infected clones did not appear different from control LZ14 clones until E7.5. It may be that $\alpha 8 \beta 1$ first affected the survival of cells that migrated into the intermediate zone and tectal plate or that after E6 fewer cells were produced, so that fewer cells migrated out of the ventricular zone. Our E6 results do not support an effect on cell production, so we favor the first explanation. Integrin $\alpha 8$ antisense-bearing cells in the ventricular zone at E9 were fewer in number than in control clones, indicating that these cells also were affected and eventually died. It is currently unknown whether the earlier-dying cells in the upper laminae and/or the relatively later-dying ventricular zone cells died because of a direct effect or an indirect effect. It is hypothesized that cells died as a direct result of the interruption of integrin signaling events involved in the suppression of apoptosis.

To further explore the possibility of cell death of $\alpha 8$ antisenseexpressing cells, previously injected tecta (on E3) of different ages (E6, E9, and E12) were analyzed for the total number of radial clones per embryo. It seemed reasonable that if $\alpha 8$ antisensecontaining cells were dying, then there should be a marked decrease in the number of radial clones per embryo by E12. We found this to be the case (Fig. 10). For this experiment, one group of embryos was injected on E3 with control virus LZ14 and another group with antisense virus LZ $\alpha 8 \mathrm{AS}$ from the same batch of eggs. At E6, E9, and E12, the tecta of several (four to six) of each type of embryo were processed histochemically for lacZpositive clones and analyzed. The mean clone number for each virus type at E6 was set as $100 \%$, and the means for later days were displayed as a percentage of this number. Controls showed a slight decrease in the number of radial clones per embryo between E6 and E12. At E12, however, LZ $\alpha 8$ AS-infected embryos showed a dramatic decrease in clones per embryo to $<5 \%$ of the number present at E6 (Fig. 10). These results indicate that $\alpha 8$ antisense-expressing cells and clones died.

To investigate the alternative possibility that $\alpha 8$ antisensecontaining cells were not dying but were migrating away from radial arrays, E9 tecta were qualitatively analyzed for the presence of cells outside radial arrays. Tectal pieces were analyzed using a dissecting microscope at a magnification at which single, blue cells could be discerned in the tissue that was cleared previously in glycerol. No evidence was found of marked cells outside the radial arrays in $\alpha 8$ antisense-infected tecta. Taken
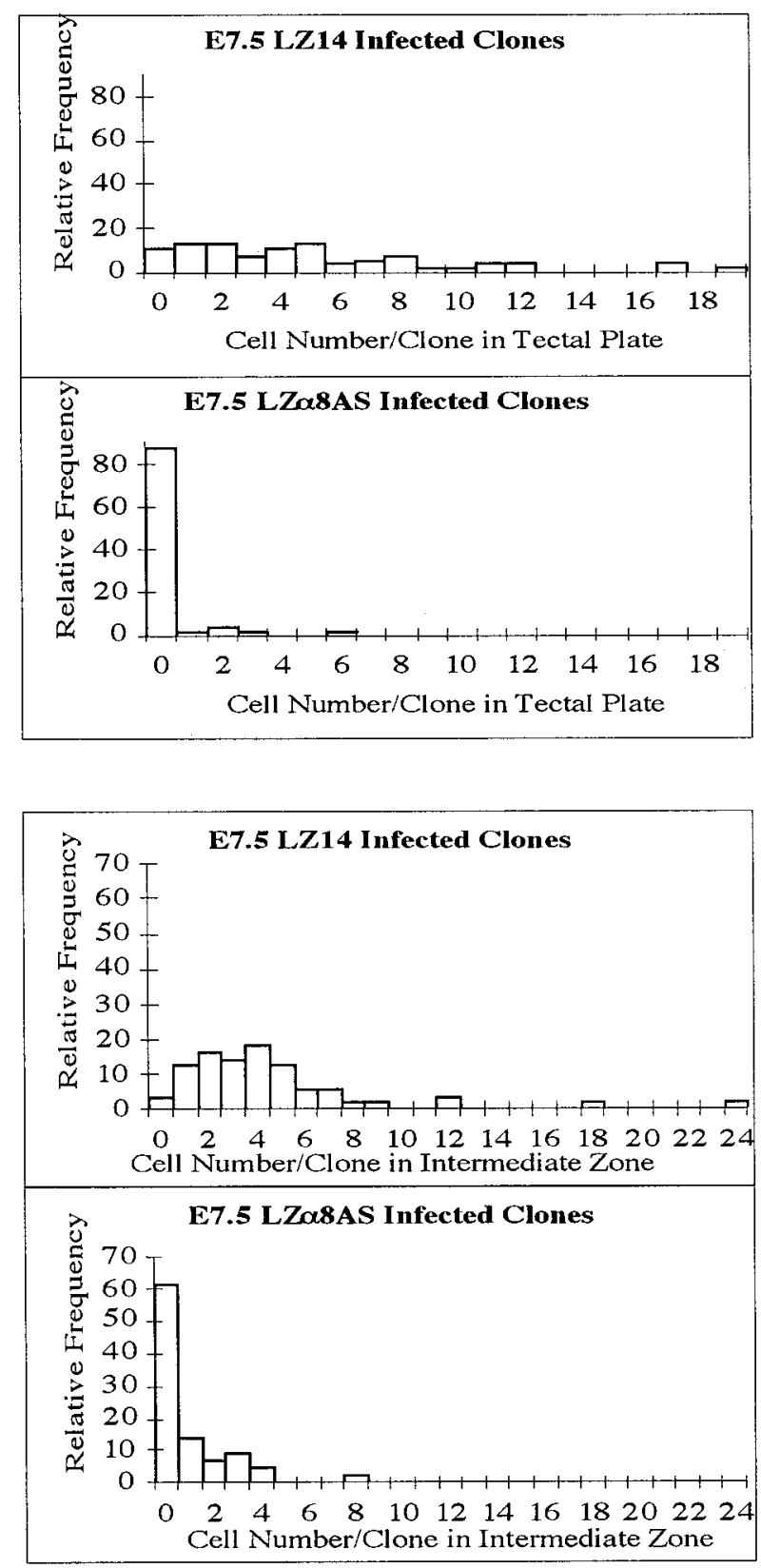

Figure 8. Relative frequency histogram of tectal clones infected with LZ $\alpha 8$ AS and LZ14 at E7.5. The top panels show the relative frequency distribution of LZ $\alpha 8$ AS- and LZ14-infected cells within the tectal plate. The bottom panels show the relative frequency distribution of LZ $\alpha 8 \mathrm{AS}$ and LZ14-infected cells within the intermediate zone.

together, our results indicate that $\alpha 8$ antisense-containing cells died and did not migrate from the radial arrays.

Although the $\alpha 8$ antisense-containing cells likely died by apoptosis, we attempted to gain evidence for this by using a very sensitive fluorescent in situ end-labeling technique (FISEL+) (Zhang and Galileo, 1998) and flow cytometry analysis. During normal tectal development between E7 and E9 there exists a widespread naturally occurring peak of FISEL + labeling (Zhang and Galileo, 1998) similar to ISEL+ labeling seen in developing mammalian cerebral cortex (Blaschke et al., 1996). The sensitive ISEL+ labeling has been regarded as a means to identify apoptotic cells, although the work of Takahashi et al. (1996) suggests 


\begin{tabular}{|c|c|c|c|}
\hline $\begin{array}{l}\text { Clonal cell } \\
\text { distribution }\end{array}$ & $\begin{array}{l}\text { LZ } \alpha 8 \text { AS } \\
(n=103)\end{array}$ & $\operatorname{LZ14}(n=65)$ & $p$ value \\
\hline Total clone & $8.8 \pm 1.0(100 \%)$ & $28.6 \pm 2.4(100 \%)$ & $<0.0001$ \\
\hline Tectal plate & $1.8 \pm 0.5(20 \%)$ & $14.8 \pm 1.2(52 \%)$ & $<0.0001$ \\
\hline Intermediate zone & $1.1 \pm 0.2(12 \%)$ & $3.6 \pm 0.4(13 \%)$ & $<0.0001$ \\
\hline Ventricular zone & $6.0 \pm 0.4(68 \%)$ & $10.1 \pm 1.0(35 \%)$ & $<0.0001$ \\
\hline
\end{tabular}

$\overline{\text { Tectal ventricles were injected with LZ } \alpha 8 \text { AS or LZ14 on E3 (approximately stage }}$ 17), and tecta were analyzed at E9. For the vector LZ $\alpha 8 A S$, the number of clones used for analysis was $103(n=103)$; for the vector LZ14, the number of clones used for analysis was $65(n=65)$. The cell distribution of a mean cell number in each layer, ventricular zone, intermediate zone, and tectal plate, as well as mean total cells per clone are expressed as the mean cell number \pm SEM. Significance of differences between control and experimental mean numbers of cells was assessed by the two-tailed $t$ test.

otherwise. The peak of labeling in tectum appears to be centered around E7.5-E8. Flow cytometry analysis of dissociated tectum cells labeled by FISEL + revealed that a considerable number of the total cells were labeled and therefore may be undergoing apoptosis. We performed FISEL+ on LZ14- and LZ $\alpha 8$ ASinfected OT cells dissociated on E8 to determine whether there was an increase in the mean level of FISEL+ labeling in $\alpha 8$ antisense-containing cells compared with control cells. We found that there was a significant increase in the mean level of FISEL+ labeling in LZ $\alpha 8$ AS-infected cells compared with LZ14 controlinfected cells (Fig. 11) $(p<0.0001)$. Similarly, there was a significant increase in the mean level of labeling for LZ $\alpha 8 \mathrm{AS}$ infected cells over uninfected cells within the same tecta $(p<$ 0.0005 ), and there was no significant difference between the mean labeling level of uninfected cells from LZ $\alpha 8 \mathrm{AS}$-infected tecta and LZ14-infected cells $(p>0.10)$. If FISEL + labeling does reflect apoptotic cells, as we believe, then the observed increase in mean FISEL+ labeling in $\alpha 8$ antisense-containing cells provides evidence that these cells died by apoptosis.

Taken together with the observations that $\alpha 8$ antisensecontaining cells disappeared from radial arrays almost completely by E12 and did not go elsewhere in the tectum, we conclude that OT cells required $\alpha 8$ integrin for their survival and that OT cells died by apoptosis when $\alpha 8$ integrin was attenuated. Because integrin signaling is known to suppress apoptosis (see Discussion), we believe that the neuronal death was a direct effect of interfering with $\alpha 8$ integrin signaling events. However, we cannot rule out that death was caused by an indirect or secondary effect after inhibition of migration. Perhaps death was a result of the inability of the migration-inhibited cells to enter the correct microenvironment for survival (e.g., neurotrophins).

\section{DISCUSSION}

We decided to study the role of two particular integrins during brain development for two reasons. First, our previous results (Galileo et al., 1992) directly implicated $\beta 1$ integrins in controlling cell migration and survival. Second, immunolocalization of fibronectin, laminin, and tenascin (Liesi, 1990; Sheppard et al., 1991; Hunter et al., 1992; Perez and Halfter, 1994; Pearlman and Sheppard, 1996; Yuasa, 1996; Yuasa et al., 1996) has indirectly implicated involvement of integrins in brain development. Here we used our previous antisense/retroviral strategy to directly implicate $\alpha 6$ integrin in cell migration and $\alpha 8$ integrin in cell survival during brain development.

Attenuation of integrin subunits $\alpha 6$ and $\alpha 8$ had different effects on the development of optic tectum cells. Our results are sum-
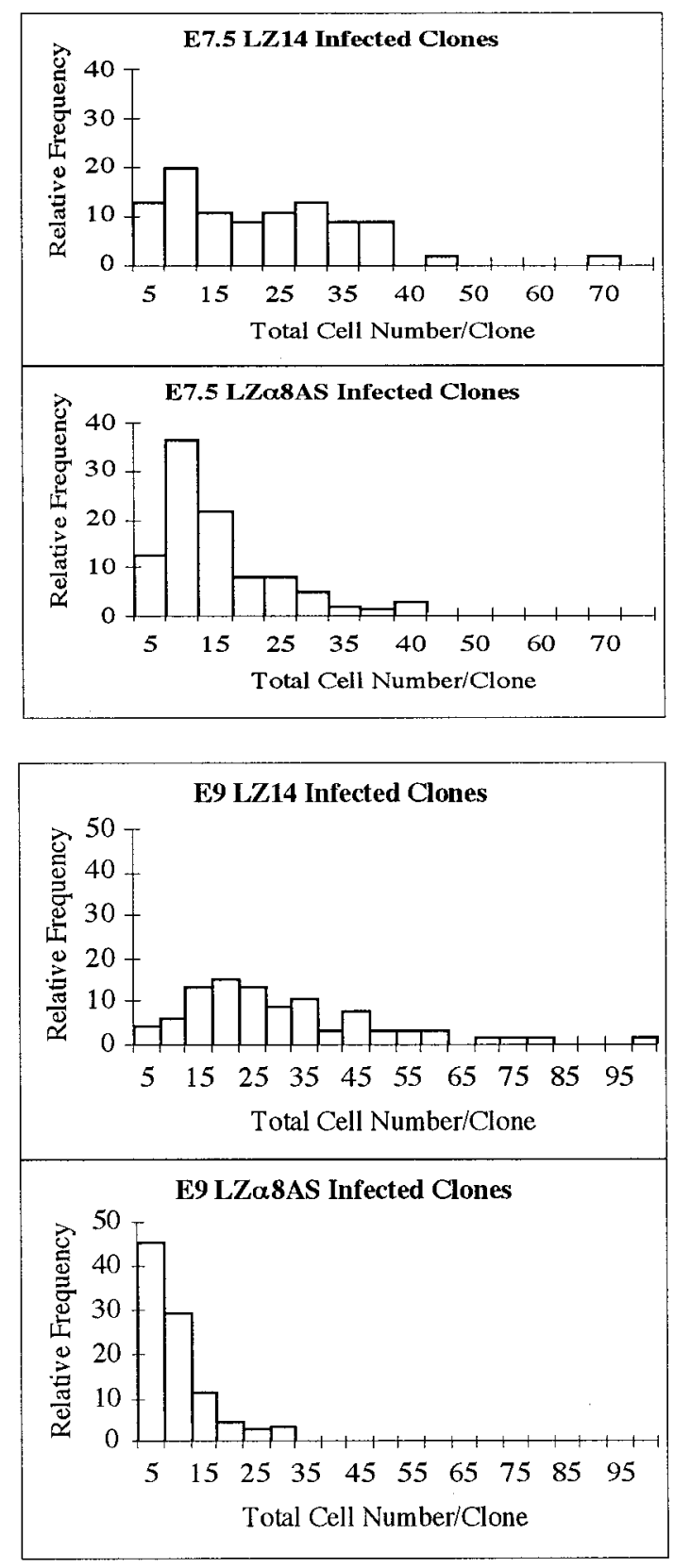

Figure 9. Relative frequency histogram of LZ $\alpha 8$ AS- and LZ14-infected clones at E7.5 and E9. The top two histograms display the relative frequency distributions of total cell number within clones at E7.5. The bottom two histograms display the relative frequency distributions of total cell number within clones at E9.

marized in a quantitative diagram in Figure 12. These results show that different integrins play different roles during brain development. Our $\alpha 6$ antisense results show that an $\alpha 6$ integrin (either $\alpha 6 \beta 1$ or $\alpha 6 \beta 4$ ) influences specifically the radial migration of a small subpopulation of tectal cells. Our $\alpha 8$ antisense results here and our previous $\beta 1$ antisense results (Galileo et al., 1992) show that $\alpha 8 \beta 1$ integrin influences cell survival in developing brain. These are the first demonstrations of roles for $\alpha 6$ and $\alpha 8$ integrins during brain development. Our work also demonstrates that multiple integrin receptors are used concurrently to perform different functions within developing brain tissue and cells.

LZ $\alpha 8$ AS reduced the level of $\alpha 8$ integrin in dissociated OT 


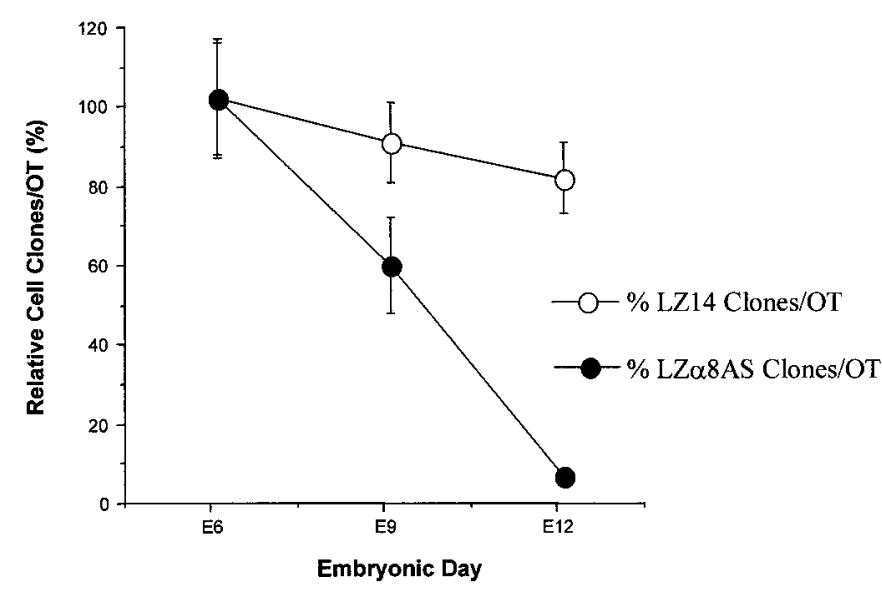

Figure 10. Disappearance of LZ $\alpha 8$ AS infected clones over time. A group of embryos were injected with either LZ $\alpha 8 \mathrm{AS}$ or LZ14 at E3, and some were killed at E6, some at E9, and some at E12. The mean cell clones per tectum at E6 are expressed as 100\%, and the mean cell clones per tectum at both E9 and E12 are expressed as the mean percentage (relative to that at E6) \pm SEM (error bars).

cells, and LZ $\alpha 6 \mathrm{AS}$ reduced $\alpha 6$ integrin in a cell line in vitro. These results were similar. Therefore, we believe that the in vivo behaviors of infected OT cells were caused by the attenuation of $\alpha 6$ and $\alpha 8$ integrin subunits. In addition, two drastically different phenotypes occurred with vectors $\mathrm{LZ} \alpha 6 \mathrm{AS}$ and LZ $\alpha 8 \mathrm{AS}$ in vivo, which act as controls for each other against nonspecific effects.

Transgenic mouse knock-outs of integrin $\alpha 6$ or $\alpha 8$ subunits have not yielded defects in brain development (GeorgesLabouesse et al., 1996; Müller et al., 1997). Our limited $\alpha 6$ antisense results may be consistent with knock-out results, because redistribution of cells within our clones was not obvious before quantitation. The loss of this subpopulation of cells may not cause any dramatic abnormalities, regardless of whether they die, survive and differentiate into another cell type, or survive and differentiate into ectopic cells of normal phenotype. Knockout integrin $\alpha 8$ mice exhibited deficits in kidney morphogenesis but no adverse effects on nervous system development. Detailed analyses of the brain may not have been preformed in these cases. In light of our results, it would be interesting to examine the colliculi of these mice in detail at appropriate developmental stages to determine whether effects similar to ours occurred.

Alternatively, our antisense results may be attributable to either species differences or other factors such as the timing of perturbation. Integrin $\alpha 6$ expression was required for early nervous system development in Xenopus laevis in vivo when attenuated by antisense $\alpha 6$ mRNA expression (Lallier et al., 1996). Knock-out mice for integrin $\alpha 1$ showed no phenotype (Gardner et al., 1996); however, experiments using injection of $\alpha 1$ antisense oligonucleotides into chick embryos resulted in neural crest and neural tube abnormalities (Kil et al., 1996). These examples suggest that in vivo results obtained from deletion or attenuation of an integrin subunit may depend on the stage of attenuation. Early attenuation in knock-out mice may result in compensation for the deletion, but this ability may be inactivated or lost at some later stage during development. Mechanisms of compensation both at the molecular and cellular levels have been postulated for integrin knock-out mice (for review, see Gullberg and Ekblom, 1997).

If $\alpha 6$ integrin was attenuated significantly in vivo as in QT6 cells, our results add more evidence that integrins control cell
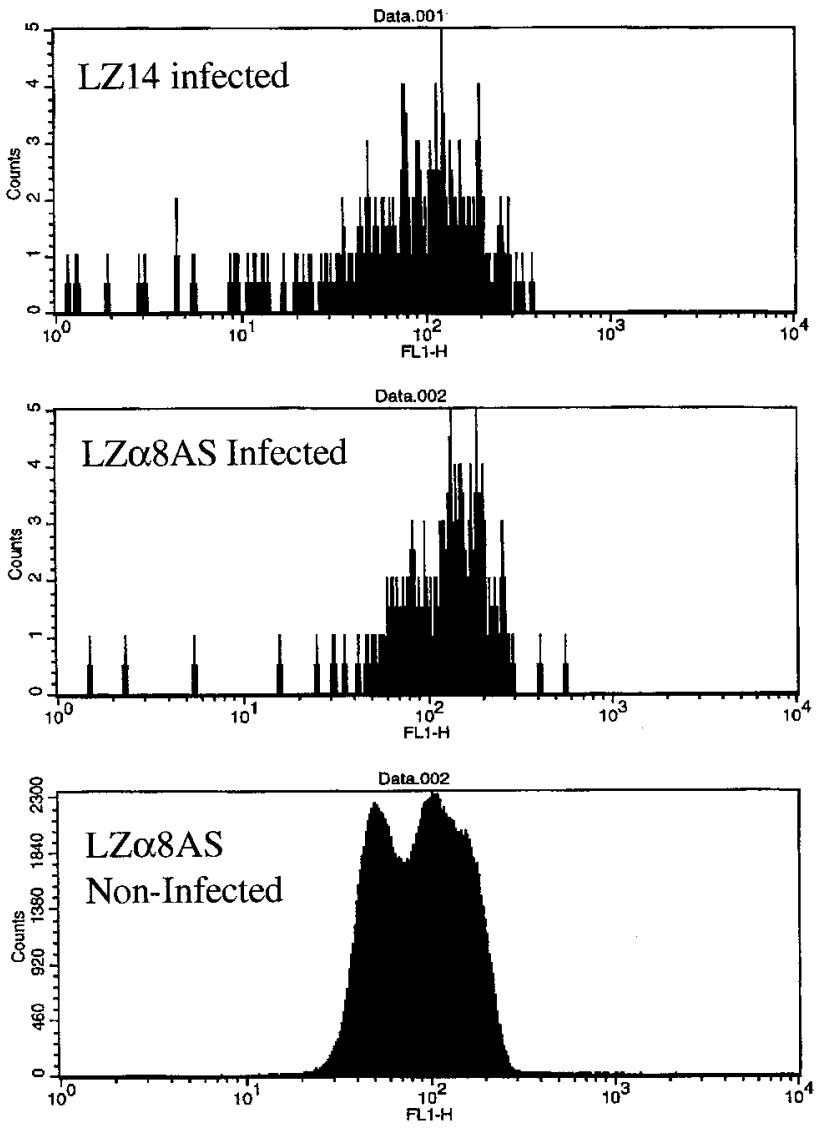

Figure 11. Flow cytometry analysis of LZ $\alpha 8$ AS-infected cells after FISEL+. The bottom panel shows the FISEL+ labeling pattern of normal uninfected cells from tecta that were injected with LZ $\alpha 8$ AS at E3 and processed at E8. At least two populations appear to be present, although overlapping. The top panel shows the FISEL+ labeling pattern of LZ14infected cells ( $p>0.10$ between means of top and bottom panels). The middle panel shows the FISEL+ labeling pattern of LZ $\alpha 8$ AS-infected cells in the same population as the bottom panel. These cells showed increased FISEL+ labeling compared with the LZ14-infected controls $(p<0.0001)$ as well as compared with uninfected cells $(p<0.0005)$. Many fewer cells are shown in the top two panels than in the bottom panel because FISEL+ labeling was measured only in the small fraction of total dissociated cells that were infected and lacZ+.

migration in developing brain (Galileo et al., 1992). This subunit appears to be involved in migration of a specific cell subpopulation that may use $\alpha 6$ integrin receptors to follow a migratory substrate to its proper destination and/or for signaling to initiate such a process. Our results suggest that neuronal subpopulations are guided to their proper laminae, at least in part, by using different integrins. Presently, very few other molecules have been implicated in controlling laminar distribution of cells in the developing brain. One system may be interactions between mouse disabled-1 (Howell et al., 1997) and a receptor for the reeler gene product (D'Arcangelo et al., 1995; Hirotsune et al., 1995; Ogawa et al., 1995), or a parallel pathway. In tectum, the $\alpha 6$ integrindependent migration process may parallel that of incoming retinal axons that use receptors to follow lamina-specific cues in the optic tectum (Yamagata and Sanes, 1995; Inoue and Sanes, 1997).

It is not known whether the $\alpha 6$ integrin-dependent cell subpopulation can eventually migrate out of the ventricular zone, can differentiate in its new location, or ultimately can survive. We speculate that these displaced neuroblasts might survive initially 


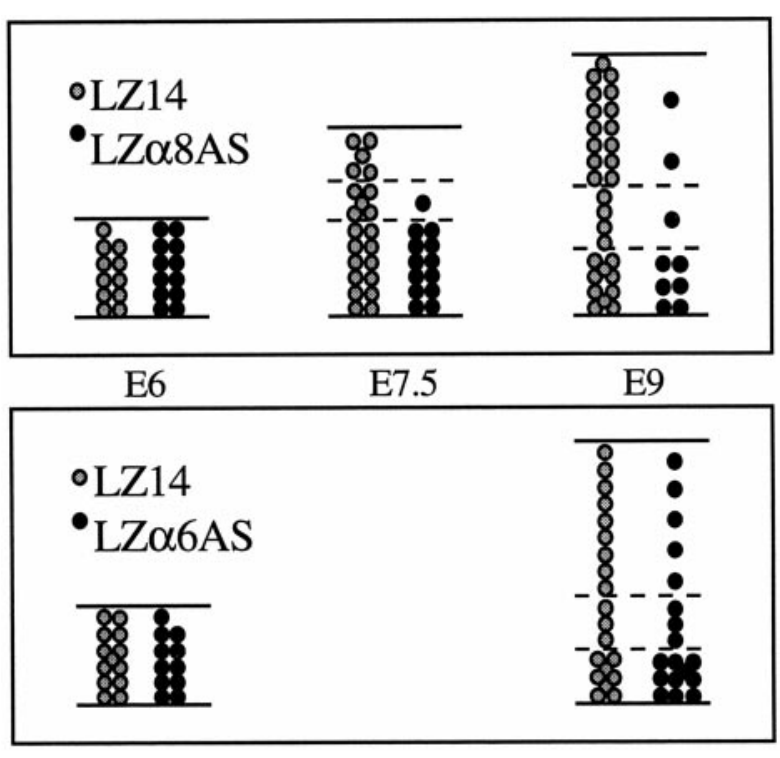

Figure 12. Summary data. The effects of antisense $\alpha 8$ and $\alpha 6$ sequences on the clonal development of tectal cells are shown in this quantitative summary diagram. Each circle, solid or stipled, represents a cell, and the number of cells shown are the mean numbers of cells at each age. Data are taken from Tables 1-5.

because of intact $\alpha 8$ integrin-substrate interactions. Death may occur later because of deprivation of neurotrophic factors or connectivity. Potential substrate molecules are also unknown. Distinct forms of laminin, other known substrates, or unknown substrates for $\alpha 6$ integrins may be present in optic tectum and on radial glia. For instance, a specific chain of laminin (B2) has been found on radial glia in mammals (Liesi, 1990, 1992), and its unknown receptor has been implicated in promoting neuronal migration (Liesi et al., 1992, 1995). Hunter et al. (1992) also reported the presence of laminin $\beta 2$ (s-laminin) in developing rat brain and on glia in culture.

Our LZ $\alpha 8$ AS results resemble previous $\beta 1$ integrin antisense results (Galileo et al., 1992), although LZ $\alpha 8$ AS affected cell survival more dramatically. The $\alpha 8$ antisense may reduce more efficiently the expression level of $\alpha 8 \beta 1$ than would the $\beta 1$ antisense, because there are many possible $\beta 1$ integrin heterodimers yet only one known $\alpha 8$ heterodimer $(\alpha 8 \beta 1)$.

We believe that death of LZ $\alpha 8$ AS-infected cells is a direct result of interfering with an integrin signaling pathway. Various reviews have discussed the role of integrin adhesion systems in the regulation of apoptosis (Dedhar and Hannigan, 1996; LaFlamme and Auer, 1996; Varner and Cheresh, 1996; Meredith and Schwartz, 1997). Their anti-apoptosis function may be mediated through signaling cascades involving focal adhesion kinase in some cases (Richardson and Parsons, 1995; Meredith and Schwartz, 1997). $\beta 1$ integrins (Scott et al., 1997) and $\alpha 5 \beta 1$ integrin (Zhang et al., 1995) support survival of cells on fibronectin, possibly by upregulating Bcl- 2 expression. $\alpha 8 \beta 1$ is also a fibronectin receptor, so it is possible that $\alpha 8 \beta 1$ inhibits apoptosis of optic tectum cells similarly. We think that $\alpha 8 \beta 1$ may inhibit apoptosis of optic tectum cells by upregulating Bcl-2 and/or other Bcl-2-like molecules or by downregulating apoptosis-promoting factors such as Bax (Deckwerth et al., 1995), changing the Bcl-2/Bax ratio in favor of cell death (Knudson and Korsmeyer, 1997; Meredith and Schwartz, 1997). Immature neurons in the developing brain migrate along radial glial fibers (Rakic, 1985, 1990). Fibronectin has been found on radial glia and is thought to be involved in radial migration of neurons in the developing mammalian cortex (Sheppard et al., 1991; Pearlman and Sheppard, 1996). Tenascin also has been found on radial glia in developing mammalian cerebellum (Yuasa, 1996; Yuasa et al., 1996). Prevention of apoptosis by the extracellular matrix is dependent on the expression and function of particular integrin heterodimers (LaFlamme and Auer, 1996), which in turn interact with particular matrix substrates. LZ $\alpha 8$ AS may have caused the loss of anchorage of tectal neurons to a substrate on radial glia, and this triggered apoptosis. It is not known whether fibronectin and tenascin are involved in the suppression of apoptosis in the optic tectum. Either or both of these molecules may be interacting with $\alpha 8 \beta 1$ integrins on developing tectal cells to facilitate cell survival or migration or both.

Recently, we found in the optic tectum an early period of apparent normal widespread programmed cell death on E7.5-E8 when extensive radial migration of neurons is taking place (Zhang and Galileo, 1998). This is when much of our experimentally induced death also occurs as a result of the antisense $\alpha 8$ vector. Therefore, a hypothesis is proposed for the involvement of $\alpha 8 \beta 1$ integrin-substrate interactions in the regulation of early neural cell survival in the optic tectum: excess cells are generated. Only a certain percentage of the newly generated neurons make and keep stable contact interactions with the radial glial scaffolds via $\alpha 8 \beta 1$ integrins. These interactions would be made in the ventricular zone and maintained into the tectal plate. Those that do not maintain contacts die. Such interactions would provide a mechanism for keeping cells alive and would control the cell number and distribution patterns in the optic tectum for later neuronal connectivity. If this hypothesis endures subsequent experimentation, then a new type of interaction (integrin-substrate) may be added to those that have been found previously to influence neuronal survival, such as neurotrophic factors and connectivity (for review, see Henderson, 1996a,b).

\section{REFERENCES}

Bayne EK, Anderson MJ, Fambrough DM (1984) Extracellular matrix organization in developing muscle: correlation with acetylcholine receptor aggregates. J Cell Biol 99:1486-1501.

Blaschke AJ, Staley K, Chun J (1996) Widespread programmed cell death in proliferative and postmitotic regions of the fetal cerebral cortex. Development 122:1165-1174.

Bossy B, Bossy-Wetzel E, Reichardt LF (1991) Characterization of the integrin $\alpha 8$ subunit: a new integrin $\beta 1$-associated subunit, which is prominently expressed on axons and on cells in contact with basal laminae in chick embryos. EMBO J 10:2375-2385.

Bronner-Fraser M, Artinger M, Muschler J, Horwitz AF (1992) Developmentally regulated expression of $\alpha 6$ integrin in avian embryos. Development 115:197-211.

Chen C, Okayama H (1987) High-efficiency transformation of mammalian cells by plasmid DNA. Mol Cell Biol 7:2745-2752.

Cheresh DA, Mecham RP (1994) Integrins: molecular and biological responses to the extracellular matrix. San Diego: Academic.

Clark EA, Brugge JS (1995) Integrins and signal transduction pathways: the road taken. Science 268:233-239.

D'Arcangelo G, Miao GG, Chen S-C, Soares HD, Morgan JI, Curran T (1995) A protein related to extracellular matrix proteins deleted in the mouse mutant reeler. Nature 374:719-723.

Deckwerth TM, Vejsada R, Poueymirou WT, Acheson A, Suri C, Conover JC, Friendman B, McClain J, Pan L, Stahl N, Ip NY, Kato A, Yancopolous GD (1995) Bax is required for neuronal death after trophic factor deprivation and during development. Neuron 17:401-411.

de Curtis I, Gatti G (1994) Identification of a large complex containing the integrin $\alpha 6 \beta 1$ laminin receptor in neural retinal cells. J Cell Sci 107:3165-3172. 
de Curtis I, Reichardt LF (1993) Function and spatial distribution in developing chick retina of the laminin receptor $\alpha 6 \beta 1$ and its isoforms. Development 118:377-388.

de Curtis I, Quaranta V, Tamura RN, Reichardt LF (1991) Laminin receptors in the retina: sequence analysis of the chick integrin $\alpha 6$ subunit-evidence for transcriptional and posttranslational regulation. J Cell Biol 133:405-416.

Dedhar S, Hannigan GE (1996) Integrin cytoplasmic interactions and bidirectional transmembrane signalling. Curr Opin Cell Biol 8:657-669.

Delwel GO, de Melker AA, Hogervorst F, Jaspars LH, Fles DLA, Kuikman I, Lindblom A, Paulsson M, Timpl R, Sonnenberg A (1994) Distinct and overlapping ligand specificities of the $\alpha 3 \mathrm{~A} \beta 1$ and $\alpha 6 \mathrm{~A} \beta 1$ integrins: recognition of laminin isoforms. Mol Biol Cell 5:203-215.

Einheber S, Schnapp LM, Salzer JL, Cappiello ZB, Milner TA (1996) Regional and ultrastructural distribution of the $\alpha 8$ integrin subunit in developing and adult rat brain suggests a role in synaptic function. J Comp Neurol 370:105-134.

Galileo DS, Gray GE, Owens GC, Majors J, Sanes JR (1990) Neurons and glia arise from a common progenitor in chick optic tectum: demonstration with two retroviruses and cell type-specific antibodies. Proc Natl Acad Sci USA 87:458-462.

Galileo DS, Majors J, Horwitz AF, Sanes JR (1992) Retrovirally introduced antisense integrin RNA inhibits neuroblast migration in vivo. Neuron 9:1117-1131.

Gardner H, Kreidberg J, Koteliansky V, Jaenish R (1996) Deletion of $\alpha 1$ integrin by homologous recombination permits normal murine development but gives rise to a specific deficit in cell adhesion. Dev Biol 301:301-313.

Georges-Labouesse E, Messadeq N, Yehia G, Cadelbert L, Dierich A, Le Meur M (1996) Absence of the $\alpha 6$ integrin leads to epidermolysis bullosa and neonatal death in mice. Nat Genet 13:370-373.

Gray GE, Sanes JR (1991) Migratory paths and phenotypic choices of clonally related cells in the avian optic tectum. Neuron 6:211-225.

Gray GE, Glover JC, Majors J, Sanes JR (1988) Radial arrangement of clonally related cells in the chicken optic tectum: lineage analysis with a recombinant retrovirus. Proc Natl Acad Sci USA 85:7356-7360.

Gullberg D, Ekblom P (1997) Integrins during development. In: Integrin-ligand interaction (Eble JA, Kühn K, eds), pp 253-267. Austin: R. G. Landes Company.

Hamburger V, Hamilton HL (1951) A series of normal stages in the development of the chick embryo. J Morphol 88:49-92.

Henderson CE (1996a) Programmed cell death in the developing nervous system. Neuron 17:579-585.

Henderson CE (1996b) Role of neurotrophic factors in neuronal development. Curr Opin Neurobiol 6:64-70.

Hirotsune S, Takahara T, Sasaki N, Hirose K, Yoshiki A, Ohashi T, Kusakabe M, Murakami Y, Muramatsu M, Watanabe S, Nakao K, Katsuki M, Hayashizaki Y (1995) The reeler gene encodes a protein with an EGF-like motif expressed by pioneer neurons. Nat Genet 10:77-83.

Howell BW, Hawkes R, Soriano P, Cooper JA (1997) Neuronal position in the developing brain is regulated by mouse disabled-1. Nature 389:733-737.

Hunter DD, Llinas R, Ard M, Merlie JP, Sanes JR (1992) Expression of s-laminin and laminin in the developing rat central nervous system. J Comp Neurol 323:238-251.

Hynes RO (1992) Integrins: versatility, modulation, and signaling in cell adhesion. Cell 69:11-25.

Inoue A, Sanes JR (1997) Lamina-specific connectivity in the brain: regulation by $\mathrm{N}$-cadherin, neurotrophins, and glycoconjugates. Science 276:1428-1431.

Kil SH, Lallier T, Bronner-Fraser M (1996) Inhibition of cranial neural crest adhesion in vitro and migration in vivo using integrin antisense oligonucleotides. Dev Biol 179:91-101.

Knudson CM, Korsmeyer SJ (1997) Bcl-2 and Bax function independently to regulate cell death. Nat Genet 16:358-363.

LaFlamme SE, Auer KL (1996) Integrin signaling. Semin Cancer Biol 7:111-118.

Lallier TE, Whittaker CA, DeSimone DW (1996) Integrin $\alpha 6$ expression is required for early nervous system development in Xenopus laevis. Development 122:2539-2554.

Liesi P (1990) Extracellular matrix and neuronal movement. Experientia 46:900-907.
Liesi P (1992) Neuronal migration on laminin involves neuronal contact formation followed by nuclear movement inside a preformed process. Exp Neurol 117:103-133.

Liesi P, Seppala, Trenkner E (1992) Neuronal migration in cerebellar microcultures is inhibited by antibodies against a neurite outgrowth domain of laminin. J Neurosci Res 33:170-176.

Liesi P, Hager G, Dodt H-U, Seppala I, Zieglgansberger W (1995) Domain-specific antibodies against the B2 chain of laminin inhibit neuronal migration in the neonatal rat cerebellum. J Neurosci Res 40:199-206.

Meredith JE, Schwartz MA (1997) Integrins, adhesion and apoptosis. Trends Cell Biol 7:146-150.

Moscovici C, Moscovici MG, Jemenez H (1977) Continuous tissue culture cell lines derived from chemically induced tumors of Japanese quail. Cell 11:95-103.

Müller U, Bossy B, Venstrom K, Reichardt LF (1995) Integrin $\alpha 8 \beta 1$ promotes attachment, cell spreading, and neurite outgrowth on fibronectin. Mol Biol Cell 6:433-448.

Müller U, Wang D, Denda S, Meneses JJ, Pedersen RA, Reichardt LF (1997) Integrin $\alpha 8 \beta 1$ is critically important for epithelial-mesenchymal interactions during kidney morphogenesis. Cell 88:603-613.

Ogawa M, Miyata T, Nakajima K, Yagyu K, Seike M, Ikenaka K, Yamamoto H, Mikoshiba K (1995) The reeler gene-associated antigen on Cajal-Retzius neurons is a crucial molecule for laminar organization of cortical neurons. Neuron 14:899-912.

Pearlman AL, Sheppard M (1996) Extracellular matrix in early cortical development. Prog Brain Res 108:119-134.

Perez RG, Halfter W (1994) Tenascin protein and mRNA in the avian visual system: distribution and potential contribution to retinotectal development. Perspect Dev Neurosci 2:75-87.

Rakic P (1985) Contact regulation of neuronal migration. In: The cell in contact (Edelman GM, Thiery JP, eds), pp 67-91. New York: Wiley.

Rakic P (1990) Principles of neural cell migration. Experientia 46:882-891.

Richardson A, Parsons JT (1995) Signal transduction through integrins: a central role for focal adhesion kinase?. BioEssays 17:229-236.

Ruoslahti E, Reed JC (1994) Anchorage dependence, integrins, and apoptosis. Cell 77:477-478.

Schnapp LM, Hatch N, Ramos DM, Klimanskaya IV, Sheppard D, Pytela $\mathrm{R}$ (1995) The human integrin $\alpha 8 \beta 1$ functions as a receptor for tenascin, fibronectin, and vitronectin. J Biol Chem 270:23196-23202.

Scott G, Casidy L, Busacco A (1997) Fibronectin suppresses apoptosis in normal human melanocytes through an integrin-dependent mechanism. J Invest Dermatol 108:147-153.

Sheppard AM, Hamilton SK, Pearlman AL (1991) Changes in the extracellular matrix components accompany early morphogenetic events of mammalian cortical development. J Neurosci 11:3928-3942.

Takahashi T, Nowakowski RS, Caviness VS (1996) The leaving or Q fraction of the murine cerebral proliferative epithelium: a general model of neocortical neurogenesis. J Neurosci 16:6183-6196.

Varner JA, Cheresh DA (1996) Integrins and cancer. Curr Opin Cell Biol 8:724-730.

Varnum-Finney B, Venstrom K, Muller U, Kypta R, Backus C, Chiquet M, Reichardt LF (1995) The integrin receptor $\alpha 8 \beta 1$ mediates interactions of embryonic chick motor and sensory neurons with tenascin-C. Neuron 14:1213-1222.

Weaver CD, Yoshida CK, de Curtis I, Reichardt LF (1995) Expression and in vitro function of $\beta 1$-integrin laminin receptors in the developing avian ciliary ganglion. J Neurosci 15:5275-5285.

Yamagata M, Sanes JR (1995) Lamina-specific cues guide outgrowth and arborization of retinal axons in the optic tectum. Development 121:189-200.

Yamagata M, Herman J-P, Sanes JR (1995) Lamina-specific expression of adhesion molecules in developing chick optic tectum. J Neurosci 15:4556-4571.

Yuasa S (1996) Bergmann glial development in the mouse cerebellum as revealed by tenascin expression. Anat Embryol 194:223-234.

Yuasa S, Kawamura K, Kuwano R, Ono K (1996) Neuron-glia interrelations during migration of purkinje cells in the mouse embryonic cerebellum. Int J Dev Neurosci 14:429-438.

Zhang Z, Galileo D (1998) Widespread programmed cell death in early developing chick optic tectum. NeuroReport, in press.

Zhang Z, Vuori K, Reed JC, Ruoslahti E (1995) The $\alpha 5 \beta 1$ integrin supports survival of cells on fibronectin and up-regulates Bcl-2 expression. Proc Natl Acad Sci USA 92:6161-6165. 